\title{
REINVENTING BANKRUPTCY LAW
}

A History of the Companies' Creditors Arrangement Act 
This page intentionally left blank 


\section{REINVENTING \\ BANKRUPTCY LAW}

A History of the Companies'

Creditors Arrangement Act

\section{VIRGINIA TORRIE}


(C) University of Toronto Press 2020

Toronto Buffalo London

utorontopress.com

Printed in the U.S.A.

ISBN 978-1-4875-0642-1 (cloth)

ISBN 978-1-4875-3413-4 (EPUB)

ISBN 978-1-4875-3412-7 (PDF)

\section{Library and Archives Canada Cataloguing in Publication}

Title: Reinventing bankruptcy law : a history of the Companies' Creditors

Arrangement Act / Virginia Torrie

Names: Torrie, Virginia, author.

Description: Includes bibliographical references and index, Identifiers: Canadiana (print) 20200179969 | Canadiana (ebook) 20200179977 | ISBN 9781487506421 (cloth) | ISBN 9781487534134 (EPUB) | ISBN 9781487534127 (PDF)

Subjects: LCSH: Canada. Companies' Creditors Arrangement Act. I

LCSH: Bankruptcy - Canada - History.

Classification: LCC KE1518.C6 T67 2020 । LCC KF1544 .T67 2020 kfmod । DDC 346.7107/8-dc23

This book has been published with the help of a grant from the Federation

for the Humanities and Social Sciences, through the Awards to Scholarly Publications Program, using funds provided by the Social Sciences and Humanities Research Council of Canada.

University of Toronto Press acknowledges the financial assistance to its publishing program of the Canada Council for the Arts and the Ontario Arts Council, an agency of the Government of Ontario.

Canada Council Conseil des Arts for the Arts

\section{du Canada}

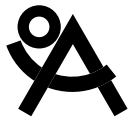

ONTARIO ARTS COUNCIL CONSEIL DES ARTS DE L'ONTARIO

an Ontario government agency un organisme du gouvernement de l'Ontario 
This book is dedicated to my maternal and paternal grandmothers: to

\section{Maryke Y. Young}

who wholeheartedly encouraged my pursuit of higher education, delighting in seeing me take up an opportunity that had not been available to her;

and in memory of

Beverley A. Torrie

who always supported my education and who set an example as a businesswoman, which is a continuing source of inspiration. 
Time is the dimension in which ideas and institutions and beliefs evolve. Douglass North, In Anticipation of the Marriage of Political and Economic Theory 